\title{
Reconstruction of flood events in an oxbow lake (Marótzugi-Holt-Tisza, NE Hungary) by using subfossil cladoceran remains and sediments
}

\author{
János Korponai,,${ }^{1,2}$ István Gyulai, ${ }^{3}$ Mihály Braun, ${ }^{4}$ Csilla Kövér, ${ }^{1}$ István Papp, ${ }^{5}$ László Forró ${ }^{6}$ \\ ${ }^{1}$ MTA - PE Limnoecology Research Group, Egyetem u. 10, 8200 Veszprém; ${ }^{2}$ Department of Chemistry and Environmental Sciences, \\ University of West Hungary, Károly Gáspár tér 4, 9700 Szombathely; ${ }^{3}$ Institute of Biology and Ecology, University of Debrecen, \\ Egyetem tér 1, 4032 Debrecen; ${ }^{4}$ Laboratory of environmental studies, Institute for Nuclear Research, Hungarian Academy of Sciences, \\ Bem tér 18/c, 4026 Debrecen; ${ }^{5}$ Department of Mineralogy and Geology, University of Debrecen, Egyetem tér 1., 4032 Debrecen; \\ ${ }^{6}$ Department of Zoology, Hungarian Natural History Museum, Baross u. 13, 1088 Budapest, Hungary \\ *Corresponding author: korponai.janos@iif.hu
}

\begin{abstract}
Oxbow lakes are important components of the floodplain systems of lowland rivers. During flood events, oxbows are connected with the main river channel, and behave as lotic systems, while during inter-flood periods, these lakes can be considered as lentic ecosystems. Rivers are generally poor in planktonic organisms and their sediments contain scarce biological remains in comparison to lentic water ecosystems. However, due to their alternating running and standing water regime, sedimentary biological remains of oxbow lakes can be used as proxies for tracking changes of past hydrological regimes. In this study we investigated how cladoceran communities respond to flood events, and whether flood events can be recognized by community analysis of cladoceran remains. A sediment core from Marótzugi-Holt-Tisza oxbow lake was analyzed for identification of past flood events based on changes in the subfossil Cladocera community. Floods were defined based on the proportion of fine sand ( $50 \mu \mathrm{m}$ grain size) in the oxbow sediments. If the fine sand portion was $<3 \%$, the water regime of the oxbow was considered as lentic, otherwise it was lotic. Both organic and pigment contents were significantly higher in the core sections deposited during lentic stages. Thirty-four Cladocera species were determined in this core, all common to littoral habitats of eutrophic shallow lakes in Hungary. One planktonic (Bosmina longirostris) and four chydorid species (Alona rectangula, Acroperus harpae, Alonella nana and Chydorus sphaericus) were dominant throughout the core and contributed $>90 \%$ of total remains. Discriminant analysis on cladoceran data confirmed that lotic and lentic hydrological stages were characterized by different Cladocera species associations. Bosmina longirostris, Chydorus sphaericus, Alona rectangula, Acroperus harpae, Leydigia leydigi, A. quadrangularis and A. nana were mainly responsible for the differences between lotic and lentic species assemblages. Our results revealed that Cladocera remains can be used to track changes in the hydrological regime of oxbow lakes.
\end{abstract}

Key words: Multiproxy reconstruction; oxbow lakes; lotic/lentic regimes; LOI; sedimental pigments; subfossil Cladocera.

Received: July 2016. Accepted: November 2016.

\section{INTRODUCTION}

Oxbow lakes are important components of the floodplain systems of lowland rivers. Rivers supply these lakes with suspended matter and nutrients during flood events, while during inter-flood periods even oxbow lakes located close to the river become isolated and develop the characteristics of lentic ecosystems. As a result, oxbow lakes behave alternatively as lotic or lentic ecosystems in relation to the hydrological regime of the river.

Flood events in oxbow lakes can be reconstructed by sediment analyses by distinguishing lotic and lentic regimes (Wolfe et al., 2006). Zooplankton biodiversity and abundance is commonly poor in lotic environments (during floods), in comparison to lentic waters (between floods) (Zsuga, 1998, 1999). These conditions are also well reflected by the remains of zooplankton species, especially cladocerans, which accumulate in sediment de- posits. As a consequence, subfossil Cladocera serve as a useful biological proxy for the evaluation of lake responses to environmental changes such as water level changes and trophic structure (Korhola and Rautio, 2001; Korponai et al., 2010a, 2011; Jeppesen et al., 2011). In Hungary, a study by Korponai et al. (2011) on cladoceran remains was used for reconstructing past changes in trophic status of Lake Balaton. Goslar et al. (1999) found high frequency of Bosmina longirostris (O.F. Müller, 1785) during the German colonization of Lake Gościąź, and a decrease of this species after the demolition of the settlement. As B. longirostris prefers eutrophic conditions (Korponai et al., 2010a, 2011), the authors concluded that the German settlers induced an increase in the lake's eutrophic status, which is in line with results provided by other sediment proxies. Galbarczyk-Gąsiorowska et al. (2009) could relate changes in cladoceran communities to decreasing water level in Stare Biele mire in Poland. Planktonic cladocerans gradually disappeared while 
macrophyte-associated species appeared and increased until finally a poor cladoceran community developed, which consisted of very rare species able to tolerate specific conditions (i.e., low $\mathrm{pH}$, low nutrient levels) in the peat phase.

According to Luoto et al. (2011), lotic conditions strongly affect cladoceran communities of boreal shallow lakes, so that sediment layers deposited during lotic stages may introduce errors in temperature and water-depth reconstructions.

In oxbow lakes trophic status is typically higher between flood events (Knowlton and Johns, 1997). However, as cladoceran distribution can be affected by different abiotic factors, we hypothesize that flood events could also play an important role in driving changes in cladoceran communities of oxbows. The aim of this study is to verify the occurrence of past flood events through the analysis of cladoceran remains, and to reconstruct the effects of flood events on cladoceran communities.

\section{METHODS}

\section{Study area}

Marótzugi-Holt-Tisza (holt=dead) is a small unprotected oxbow lake (length $1.8 \mathrm{~km}$, width $60 \mathrm{~m}$, area 10 ha) located at the left side of The River Tisza (at the $568^{\text {th }}$ river km), close to the Gávavencsellő village in NE Hungary (N 48.175611, E 21.612306, Fig. 1).

The River Tisza is one of the largest rivers in Central Europe, and the largest water flow of the Hungarian Plain. It is $946 \mathrm{~km}$ long, and the catchment area is $157,186 \mathrm{~km}^{2}$. The water regime of the River Tisza is very variable. The highest water levels occur at the time of snow melt between February and April. A second high water level stage frequently occurs in June, due to intense seasonal rainfalls. The lowest water levels are commonly measured from August to the end of September.

From an economical point of view, the Tisza is the most important river in Hungary, since it provides the largest irrigation water supply for cultivated areas in the country (234-265 kha in 1970-80, Lászlóffy, 1982). Before its regulation, the River Tisza was surrounded by large floodplains covering a total area of $19,637 \mathrm{~km}^{2}, 4770 \mathrm{~km}^{2}$ of which were permanently inundated. Therefore, the Tisza floodplain occupied $21 \%$ of the country, while $5 \%$ was permanently inundated (Botár and Károlyi, 1971).

In the late $19^{\text {th }}$ century, a complex drainage system was constructed, consisting of floodgates, artificial river beds and channels. Meanders were cut off, reducing the length of the River Tisza from $1420 \mathrm{~km}$ to $946 \mathrm{~km}$. Altogether 112 meanders were isolated from the river-bed and

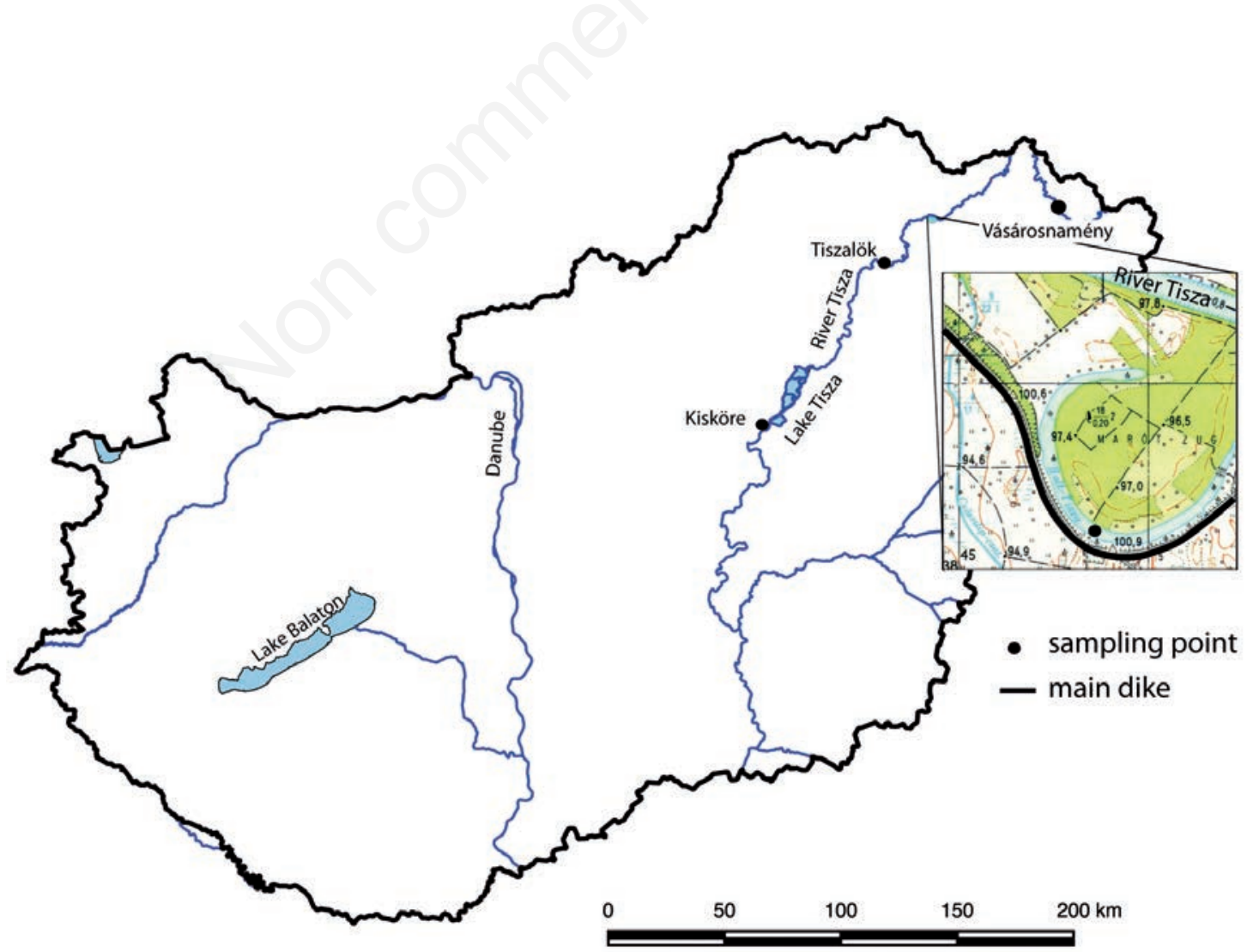

Fig. 1. Map showing the location of the Marótzugi-Holt-Tisza and the coring point. 
converted into oxbow lakes (Lászlóffy, 1982). By cutting the bends, the slope of the river-bed increased, thus increasing current velocity and kinetic energy of the river. This was supposed to prevent sediment build-up in the riverbed, as the rates of erosional and depositional processes became balanced. According to the present nomenclature, oxbows lying within the river floodplain are called unprotected (plesiopotamon), while those that are located outside of levees are defined as protected (paleopotamon). Unprotected oxbows are frequently affected by floods therefore their sediments become laminated due to sedimentation of organic matter following floods. River canalization created 80 oxbow lakes from the River Tisza. Most of them are unprotected and highly affected by floods, which makes them ideal water ecosystems for studies on of flood events. Previous studies on the sediments of the River Tisza oxbows revealed that heavy metal pollution was a regular occurrence due to ore mining in Maramures County in Romania (Braun et al., 2000, 2010). Studies by Korponai et al. (2010b, 2010c) showed that Cladocera communities represent an outstanding portion of biodiversity of oxbows lakes.

Following the reclamation scheme, a large bend of the River Tisza was isolated in 1860 and the Marótzugi-HoltTisza oxbow was established (Pálfai, 2001). This oxbow lake was chosen as a study site due to its known age and its favorable logistics. Marótzugi-Holt-Tisza oxbow is unprotected and situated between dikes and the river channel. The biota of this lake is particularly rich, and has been registered as a national nature reserve and wildlife sanctuary (Hortobágy National Park). Moreover, it was selected as part of the pilot project area for the PHARE-sponsored Hungarian National Biodiversity Monitoring Program (Müller et al., 2000).

\section{Coring}

A $463 \mathrm{~cm}$ long undisturbed sediment core was collected using a rod-operated piston corer from the deepest part of the oxbow ( 2m depth, Fig. 1) in spring in 2009. Subsamples $\left(1 \mathrm{~cm}^{3}\right)$ were taken at $2 \mathrm{~cm}$ intervals and analyzed for grain size distribution, organic content, subfossil photosynthetic pigments and Cladocera remains.

\section{Sediment chronology}

Historical records of major flood events at River Tisza were used to determine the chronology of the sediment core. A public database of stream flow of the River Tisza is available at http://www.hydroinfo.hu. Daily stream flow has been recorded since 1856 . The largest floods were determined by selecting events exceeding the highest flood warning level (III level: $800 \mathrm{~cm}$ ) at the staff gage at Vásárosnamény. Based on the time of establishment, the age of the core bottom was set at 1860 . The next time horizon is the trace of a 1888 flood, which was one of the highest ever-recorded floods of River Tisza (Nyárády, 1900; Lászlóffy, 1982; Braun et al., 2000).

Braun et al. (2010) drilled a long sediment core in a nearby site of Marótzugi-Holt-Tisza in 1997, and published a ${ }^{137} \mathrm{Cs}$ based chronology for Marótzugi-Holt-Tisza. We could successfully apply the same ${ }^{137} \mathrm{Cs}$ chronology to our sediment core after parallelizing the LOI profiles of the two cores.

\section{Grain size and subfossil pigment analyses}

To determine the grain size distribution, sediment subsamples were oven-dried at $105^{\circ} \mathrm{C}$ for at least $24 \mathrm{~h}$ before recording dry mass. Dried and grinded samples were mixed with $0.5 \mathrm{ml} 0.002 \mathrm{M}$ sodium-oxalate, then $2 \mathrm{ml}$ concentrated glycerin were added. The samples were analyzed for particle size using a Malvern Mastersizer 2000. This system measures volumetric grain sizes between 0.1$2000 \mu \mathrm{m}$ by analyzing in situ the angle of refraction of a laser beam that is aimed through the container holding the sediment-diluent mix. Flood events were arbitrary defined as sediment layers containing more than $3 \%$ of fine sand (50 $\mu \mathrm{m}$ grain size). When the fine sand portion was less than $3 \%$ we defined the water regime of the oxbow as lentic, otherwise it was lotic. Organic sediment content was determined as lost on ignition (LOI) according to standardized methods (Heiri et al., 2001).

Subfossil photosynthetic pigments were extracted with acetone and determined spectrophotometrically as chlorophyll degradation residues (SPDU, subfossil pigment degradation units). The absorbance of the liquid phase was measured at 666 and $750 \mathrm{~nm}$ after sedimentation. The weight of the solid phase was measured after evaporating the acetone and drying until constant weight. SPDU values were calculated according to Vallentyne (1955).

\section{Subfossil cladoceran}

Subsamples for the subfossil cladoceran analysis were deflocculated in $10 \% \mathrm{KOH}$. After the $\mathrm{KOH}$ treatment, sediment samples were treated with $10 \% \mathrm{HCl}$ in order to remove carbonaceous particles, and with 40\% HF (for $2 \mathrm{~h}$ ) to eliminate sand and clay fractions (Frey, 1986). Cladocera remains were collected by sieving through a $35 \mu \mathrm{m}$ mesh (Frey, 1986).

Only well preserved chitinous remains (headshields, carapaces, post-abdomens, post-abdominal claws, and ephippia) were considered to determine the density of Cladocera species. Fragments were counted only if unambiguous diagnostic marks were evident. The most frequent body parts of each taxon were used to estimate of the abundance of individuals as density ( $\mathrm{n}$. ind $\mathrm{cm}^{-3}$ of fresh sediment). The composition of the Cladocera community was estimated based on the determination of at 
least 300 individuals in each subsample (Korhola and Rautio, 2001). Taxonomical identification was carried out according to Frey $(1950,1962,1988,1991)$, Goulden and Frey (1963), Gulyás and Forró (1999), Sebestyén (1965, 1969, 1970, 1971), Szeroczyńska and Sarmaja-Korjonen (2007), and Whiteside et al. (1978).

\section{Statistical analyses}

Statistical analyses were carried out on Cladocera logtransformed $(\log (\mathrm{x}+1))$ density data. We used hierarchical clustering on transformed data to reveal temporal changes in species structure. After calculating the Euclidean distances, the ward agglomerative cluster analysis was applied. Constrained cluster analysis was done to obtain homogeneous Cladocera assemblage zones. Clusters were formed on the basis of minimal within-group squared Euclidean distances between objects (CONISS, Grimm, 1987). Significant stratigraphic zones were determined by applying the broken stick model on CONISS clustering.

The classification of stages characterized by different water regime (lotic and lentic) was tested by linear discriminant analysis (LDA) applied to transformed cladoceran data. Differences in LOI, SPDU and LDA during lotic and lentic stages were tested by Kruskall-Wallis (K-W) test. Similarity percentage (SIMPER) analysis based on BrayCurtis dissimilarity index was applied to outline cladoceran species responsible for community changes during lotic and lentic water regimes. Lowess smoothing was applied for discriminant scores with 0.1 span. All statistical analyses were performed in the $\mathrm{R}$ statistical programming language (R Development Core Team, 2010) using the rioja (Juggins, 2009) and vegan (Oksanen et al., 2016) packages.

\section{RESULTS}

\section{Sediment description and lithology}

The entire length of the sediment sequence was $463 \mathrm{~cm}$, and four sections were distinguished on the basis of their different aspect (Fig. 2). The oldest samples $(463-201 \mathrm{~cm}$ depth) were characterized by alternating layers of coarse

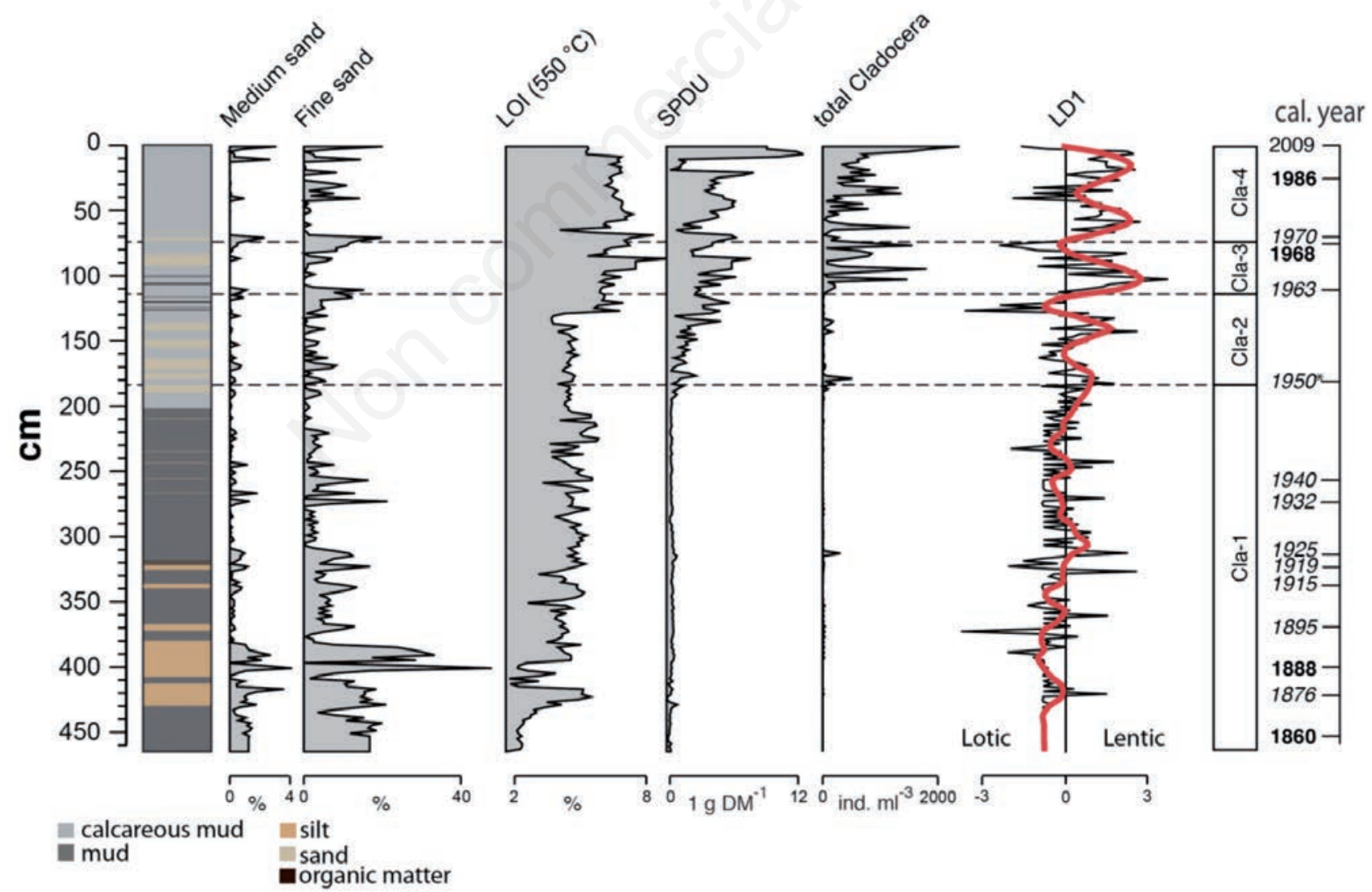

Fig. 2. Stratigraphy plot for medium and fine sand fractions in grain size distribution, loss on ignition (LOI), sediment pigment degradation units (SPDU), total Cladocera abundances and discriminant (LDA) scores in the sediment core of Marótzugi-Holt-Tisza oxbow. Red line: lowess smoothing of LD scores with 0.1 span; bold numbers indicate time horizons: 1888 largest historical flood; 1968 and 1986 according to ${ }^{137} \mathrm{Cs}$ based dating from Braun et al. (2010), numbers in italics refer to inferred dates of major floods. 
sand and clay silt. Organic matter contents were low (around 2\%) in the deepest layers $(463-431 \mathrm{~cm}$ ), which contained coarse calcareous concretions between 459-454 $\mathrm{cm}$ (Fig. 2). From $431 \mathrm{~cm}$ to the top high clay content was found, generally accompanied by sandy and coarse layers of different thickness, and by thin black organic bands. Organic matter (LOI\%) content varied between 3 and 9\% of dry matter. Two further subsections could be distinguished by LOI (Fig. 2). The lower subsection (431-130 cm depth) had lower LOI content ( $4 \%)$, while values increased up to $4-9 \%$ (mean=6\%) above $130 \mathrm{~cm}$ depth. Between 431 and $201 \mathrm{~cm}$ depth only coarse silt and sand layers were found (Fig. 2). Thick coarse sand and clay layers were found at 431-413, 410-380, and 375-369 cm depth, while thinner sand bands were recognized at 346348 , and 331-330 cm. Finally, an organic rich sand belt was found between 325 and $319 \mathrm{~cm}$ (Fig. 2). Thin sand bands were also recognized at 265, 255, 232, $210 \mathrm{~cm}$ (Fig. 2). From $200 \mathrm{~cm}$ to the core top, eight thin black bands with high organic content were found at 127, 126, 125, $121,116,106,101$ and $100 \mathrm{~cm}$, and further light brownish layers at 93-85, 73-70, and $68 \mathrm{~cm}$. SPDU content increased from $194 \mathrm{~cm}$ depth to the core top (Fig. 2). Average SPDU was $0.1671 \mathrm{~g} \mathrm{DM}^{-1}$ between $462-190 \mathrm{~cm}^{-1}$ $3.439 \mathrm{~g} \mathrm{DM}^{-1}$ from $190 \mathrm{~cm}$ to the core top.

\section{Core chronology}

Eleven large flood events were recognized in the hydrological history of the River Tisza. The mark of a large disturbance in the sediment record was found at $454 \mathrm{~cm}$ as a calcareous concretion (Fig. 2). Digging new riverbed and isolating the river bend caused a large disturbance, and the corresponding sediment layer was therefore assumed as the time horizon of oxbow establishment in 1860. Three thick coarse sandy- silt layers at 431-413, 410-380, and 375-329 $\mathrm{cm}$ depth were interpreted as deposited between the 1870 s and 1895 . In fact, particularly large floods were historically recorded in 1876,1881 , 1888 and 1895 . As peaks of medium size sand particle fractions mark the beginning of flood events (Schweitzer et al., 2002), these layers were selected to indicate 1876, 1881, 1888 and 1895 years, respectively (Fig. 2). Sandy clay layers and peaks of medium size sand particle fractions at 340, 324, 315, 274, 258, 110, 70 and $42 \mathrm{~cm}$ were interpreted as markers of large historical floods in 1915, 1919, 1925, 1932, 1940, 1964, 1970 and 1979. The increase in LOI and SPDU values from $185 \mathrm{~cm}$ depth to the sediment top was interpreted as time horizon for the beginning of the building of a large dam and a reservoir close to the village Tiszalök. This reservoir could stabilize the water regime of Marótzugi oxbow, since the dam at Tiszalök has a backwater effect in increasing the minimal water level which reaches the $628^{\text {th }}$ river $\mathrm{km}$.

Average sedimentation rates were estimated by apply- ing a linear model to the core depth-flood profile. Values were high, ranging between 3.05-3.62 $\mathrm{cm} \mathrm{y}^{-1}$, below 75 $\mathrm{cm}$ depth, and gradually decreased down to $1.1 \mathrm{~cm} \mathrm{y}^{-1}$ in the upper core section. During periods of enhanced flood frequency (i.e.,1881-95, 1932-40, 1940-50,1963-68, 1968-1970) sedimentation rates were particularly high, i.e., $4.3,5.7,7.3,5.7$ and $7 \mathrm{~cm} \mathrm{y}^{-1}$ respectively.

\section{Subfossil Cladocera}

No Cladocera remains were found in the deepest core section between 462 and $430 \mathrm{~cm}$. Very few remains were found in the sediment layers between $428-184 \mathrm{~cm}$, while Cladocera abundances gradually increased from the core bottom to the surface (Fig. 2).

Overall, 34 Cladocera species were found in the studied sediments sequence (Fig. 3). All the species are characteristic for littoral habitats of eutrophic shallow lakes, with dense macrophytes belts. The hierarchical clustering grouped the identified cladoceran species according to their abundance into four clusters. Only one species, the planktonic $B$. longirostris, was included in the first cluster, though remains of this species dominated the Cladocera assemblages throughout the whole core (Fig. 3). Alona rectangula (Sars, 1862) and Chydorus sphaericus (O.F. Müller, 1776) were the characterizing species of the second cluster. Density of these euryecious species, which are very common in the majority of freshwaters, was high in layers between 110 and $70 \mathrm{~cm}$ depth. These species are. The third cluster included fourteen species, which were present throughout the core though with low abundances. Rare species were grouped into the fourth cluster.

Four statistically significant zones were distinguished along the core on the basis of abundance of Cladocera remains.

\section{Cl-1 zone (462-184 cm)}

Albeit a number of the deepest core layers were empty (Fig. 2), remains of 30 cladoceran species were found in this zone (Fig. 3). Species abundances were very low (1-100 ind $\mathrm{cm}^{-3}$ ) except for $B$. longirostris, which reached a maximum of 300 ind $\mathrm{cm}^{-3}$ (Fig. 2) at $312 \mathrm{~cm}$. The zone was characterized by a variety of phytophilous chydorids, which were included in the second and third species cluster. Pelagic $B$. longirostris was the dominant species, but C. sphaericus, A. rectangula, Diparalona rostrata (Koch, 1841), Eurycercus lamellatus (O. F. Müller, 1785), and Acroperus harpae (Baird, 1834) were also very abundant in this zone (Fig. 3).

\section{Cl-2 zone (184-112 cm)}

This zone was characterized by low numbers of Cladocera remains, corresponding to total species densities varying between 0.5 and 516 ind $\mathrm{cm}^{-3}$ (Fig. 3). The 


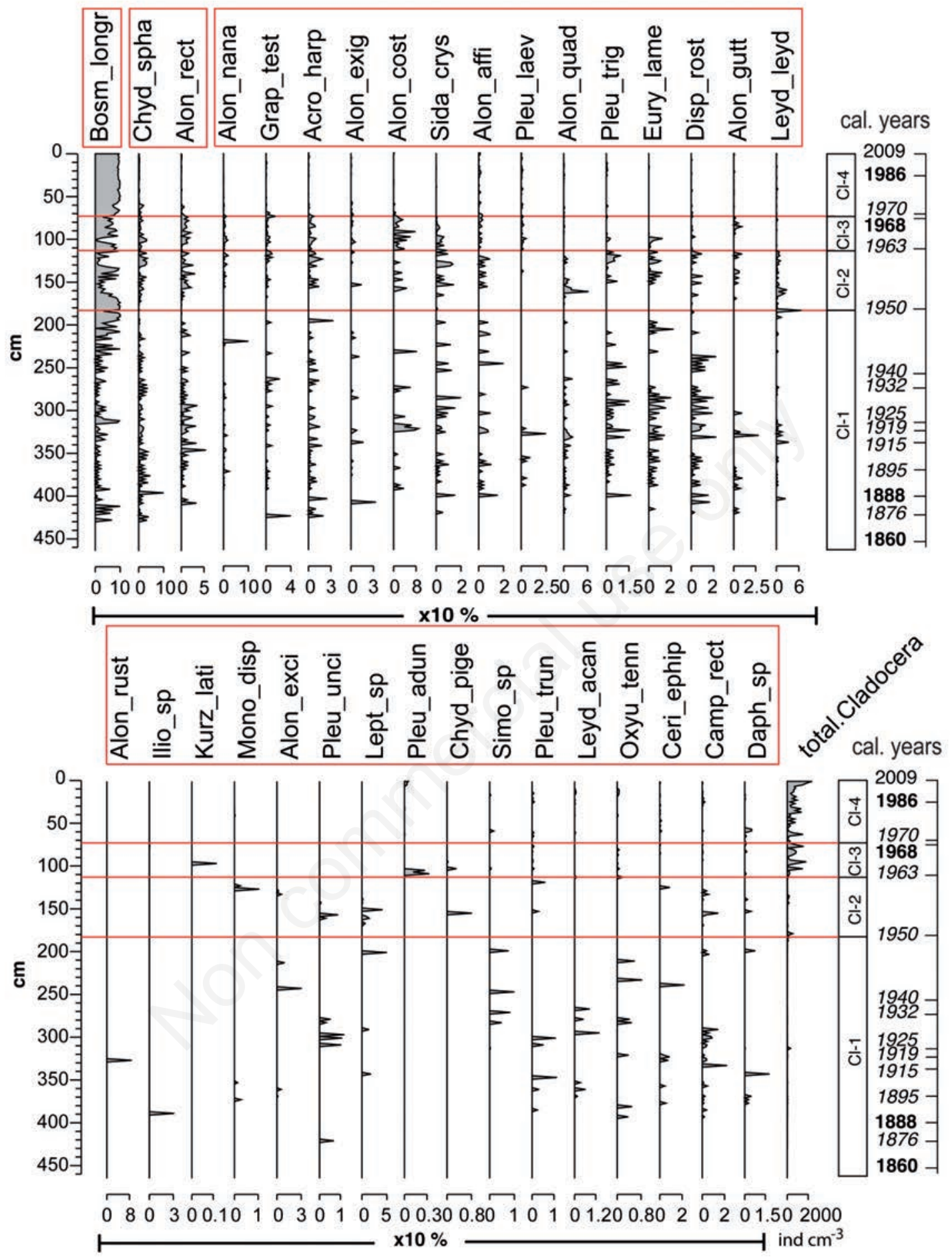

Fig. 3. Cladocera statigraphy for Marótzugi-Holt-Tisza oxbow. Bosm_long: Bosmina longirostris, Alon_nana: Alonella nana, Grap_test: Graptoleberis testudinaria, Acr_harp: Acroperus harpae, Alon_exig: Alonella exigua, Alon_cost: Alona costata, Sida_crys: Sida crystallina, Alon_affi: Alona affinis, Pleu_laev: Pleuroxus laevis, Alon_quad: Alona quadrangularis, Pleur_trig: Pleuroxus trigonellus, Eur_lame: Eurycercus lamellatus, Disp__ost: Disparalona rostrata, Alon_gutt: Alona guttata, Leyd_leyd: Leydigia leydigi, Chyd_spha: Chydorus sphaericus, Alon_rect: Alona rectangula, Alon_rust: Alona rustica, Ilio_sp: Iliocryptus sp., Kurz_lati: Kurzia lattissima, Mono_disp: Monospilus dispar, Alon_exci: Alonella excisa, Pleu_unci: Pleuroxus uncinatus, Lept_sp: Leptodora kindti, Pleu_adun: Pleuroxus aduncus, Chyd_pige: Chydorus piger, Simo_sp: Simocephalus sp., Pleu_trun: Pleuroxus truncatus, Leyd_acan: Leydigia acanthocercoides, Oxyu_tenn: Oxyurella tenuicaudis, Ceri_ephip: Ceriodaphnia ephippia, Camp_rect: Camptocercus rectirostris, Daph_sp.: Daphnia sp., 
number of Cladocera species (26) in this zone was slightly lower with respect to zone 1 . The most common species was again $B$. longispina, which accounted for an average of $80 \%$ of total cladoceran abundances. The following most abundant five species, i.e., C. sphaericus, A. rectangula, Leydigia leydigi (Schoedler, 1863), Alona quadrangularis (O. F. Müller, 1785) and A. harpae, accounted together only for $1 \%$ of Cladocera, while other cladocerans species occurred with very low densities and their contribution remained below 1\% (Fig. 2).

\section{Cl-3 zone (112-72 cm)}

Cladoceran species richness was similar to the previous zone, as 28 species were identified from the remains. B. longirostris accounted for the highest portion $(51 \%)$ of cladoceran abundance, while $A$. rectangula, $C$. sphaericus, and Alonella nana (Baird, 1850) were found with a slightly higher than $5 \%$ (Fig. 3).

\section{Cl-4 zone (72-0 cm)}

In the top zone, 28 Cladocera species were identified, among which $B$. longirostris again showed an overwhelming dominance exceeding $90 \%$ of the total Cladocera abundance. Only C. sphaericus reached a $3 \%$ of the total Cladocera abundance, while all the other species did no exceed 1\% (Fig. 3).

SIMPER analysis revealed that $B$. longirostris, $C$. sphaericus, A. recangula, A. harpae, L. leydigi, A. quadrangularis, and $A$. nana were the most important species in determining the dissimilarity of cladoceran assemblages during lotic and lentic stages in the oxbow lakes. The species number was somewhat higher in lentic layers than in lotic ones ( 31 and 28 respectively). Remains of $\mathrm{Il}$ iocryptus sp. (Sars, 1862) and Monospilus dispar (Sars, 1862) were only found in lotic layers, while remains of Alona rustica (Scott, 1895), Alonella excisa (Fischer, 1854), Chydorus piger (Lilljeborg, 1853), Kurzia latissima (Kurz, 1875) and Simopcephalus sp. (Schoedler, 1858) occurred only in lentic ones, the others were common to both. Lentic layers also contained more remains, and average cumulative density of lentic cladocerans was twice so high that of lotic ones $\left(23,986\right.$ ind $\mathrm{cm}^{-3}$ and 11,685 ind $\mathrm{cm}^{-3}$, respectively).

\section{Statistical analysis of water regime states}

Linear discriminant analysis (LDA) of subfossil cladoceran assemblages confirmed the differences between lotic and lentic water regime stages. Group centroids of the LDA scores of the different water regimes were well significantly separated (Wilks's $\lambda=0.7866$, $d f=1, P<0.05$, Fig. 4), and LDA scores were significantly correlated with the proportion fine sand $(\mathrm{r}=-0.3695, \mathrm{t}=-6.0434, \mathrm{df}=231, \mathrm{P}<0.001)$. LDA scores were positive during lentic stages, while nega- tive scores reflected lotic conditions. Smoothed LDA discriminant scores exhibited strong negative correlation with fine sand fraction $(\mathrm{r}=-0.4658, \mathrm{t}=-8.0006, \mathrm{df}=231, \mathrm{P}<0.001)$. LOI content correlated negatively with the fine sand fraction $(\mathrm{r}=-0.3288, \mathrm{t}=-5.2918, \mathrm{df}=231, \mathrm{P}<0.001)$, and positively with LDA scores $(\mathrm{r}=0.3169, \mathrm{t}=5.0795, \mathrm{df}=231, \mathrm{P}<0.001)$. Furthermore, SPDU exhibited a weak negative correlation to the fine sand fraction $(\mathrm{r}=-0.1622, \mathrm{t}=-2.4996, \mathrm{df}=231$, $\mathrm{P}<0.013$ ), as well as a positive relation with discriminant scores $(\mathrm{r}=0.3168, \mathrm{t}=5.0768, \mathrm{df}=231, \mathrm{P}<0.001)$.

Lotic sediment layers showed significantly lower LOI and SPDU values (LOI: K-W test, $\chi^{2}=9.9031, \mathrm{df}=1$, $\mathrm{P}<0.01$; SPDU: $\mathrm{K}-\mathrm{W}$ test, $\left.\chi^{2}=6.7706, \mathrm{df}=1, \mathrm{P}<0.01\right)$. In order to test for significant differences in Cladocera community composition between lotic and lentic stages, we redefined lotic and lentic regimes by LDA scores. Layers with negative LDA scores were considered as lotic, while layers with positive LDA scores were put into lentic groups. Both LOI and SPDU contents were significantly higher in LDA based lentic sediment layers (LOI: K-W test, $\left.\chi^{2}=29.165, \mathrm{df}=1, \mathrm{P}<0.001\right)$; SPDU: $\mathrm{K}-\mathrm{W}$ test, $\left.\chi^{2}=42.352, \mathrm{df}=1, \mathrm{P}<0.001\right)$.

\section{DISCUSSION}

Our sediment core was $120 \mathrm{~cm}$ longer than the core analyzed by Braun et al. $(2000,2009)$, and it covered a time span of 150 years, i.e., from oxbow establishment to the present. The estimated average sedimentation rate $\left(3.53 \mathrm{~cm} \mathrm{y}^{-1}\right)$ agrees with the values reported by Braun et al. (2009). The sediment record represents two main developmental stages of Marózugi-Holt-Tisza. From the oxbow establishment in 1860 to 1950 the water regime of the lake was determined by height and duration of floods (Fig. 2). Sedimentation rates were quite high, with a mean value of $3.6 \mathrm{~cm} \mathrm{y}^{-1}$. The construction of a large dam for electricity generation and irrigation supply for the eastern part of Hungary was started in 1950 and concluded in 1959 at Kisköre (Fig. 1). The dam has increased minimum water levels in the riverbed by $3 \mathrm{~m}$ and its effect can be recognized upstream for 623 river km (Lászlóffy, 1982). This enhanced the groundwater inflow to the oxbow, which in turn stabilized its water regime and established stable lentic conditions (Babka et al., 2011).

Increasing organic materials and pigment contents were measured in the sediments of Marózugi-Holt-Tisza after 1950 (Fig. 2). Since mero- and euplanktonic algae exhibit higher production in lentic or slow running waters (Istvánovics and Honti, 2011), and high organic material and pigment contents are found in sediments of highly productive lakes (Korponai et al., 2010a, 2011), the increased LOI and SPDU content has been interpreted as a marker for to the development of lentic conditions in the oxbow since 1950. Size distribution of sediment sand 
fractions was used for tracking flood events. The bulk of the suspended solids (SS) arrive and settle in the floodplain at the beginning of a flood (Csépes et al., 2002; Schweitzer et al., 2002), and loading depends on the intensity of flush. In fact, coarser fractions settle and accumulate in the floodplain regions closer to the riverbed, while finer particles settle in oxbows as SS (Kiss and Fejes, 2000). Therefore, high proportions of medium and fine sand fractions in sediment of Marotzugi-Holt-Tisza may correspond to major flood events. Using the proportions of sand fractions of sediment layers to define lotic (during floods) and lentic stages (in periods between floods) of the oxbow studied, we found significantly higher LOI and SPDU contents in lentic stages in the sediment profile (Fig. 2).

Reconstructed Cladocera communities of MarotzugiHolt-Tisza oxbow consisted of species which are very common in Hungary, and can be collected from almost all types of lakes and ponds. The observed shifts in Cladocera communities reflected environmental changes in the oxbow. Absence of Cladocera remains in the deepest core layers likely indicate that this sediment section represents the orig- inal riverbed (Fig. 3). Zsuga (1981) found no benthic cladocerans in the upper portion of River Tisza, but she found some species with very low densities in the lower river stretch. Moreover, investigations of the stream complex of the lower River Tisza revealed structured zooplankton communities in slow-flowing streams and in oxbows (Pujin et al., 1986; Pujin and Ratajac, 1988; Ratajac, 1989, 1992). Regime shifts from lotic to lentic conditions of large rivers in Hungary (River Danube and River Tisza) could be associated to increasing zooplankton diversity and density (Vadadi-Fülöp et al., 2008, 2009; Zsuga, 1998).

As very few cladoceran remains were found in Cl-1 zone, we interpreted this section as deposited during a lotic, flood-determined stage (Fig. 3). Since 1950, the oxbow has become more lentic, as confirmed by the pattern in the smoothed curve of LDA scores, which serves as a proxy for water regime shift. In fact, LDA scores remain negative during lotic stages, while become positive during lentic stages of the Marótzugi-Holt-Tisza (Fig. 2).

Oxbow lakes and shallow reservoirs typically show dense macrophytes beds with high cladoceran abundances (Gulyás and Forró, 1992; Zsuga et al., 2004, Korponai et

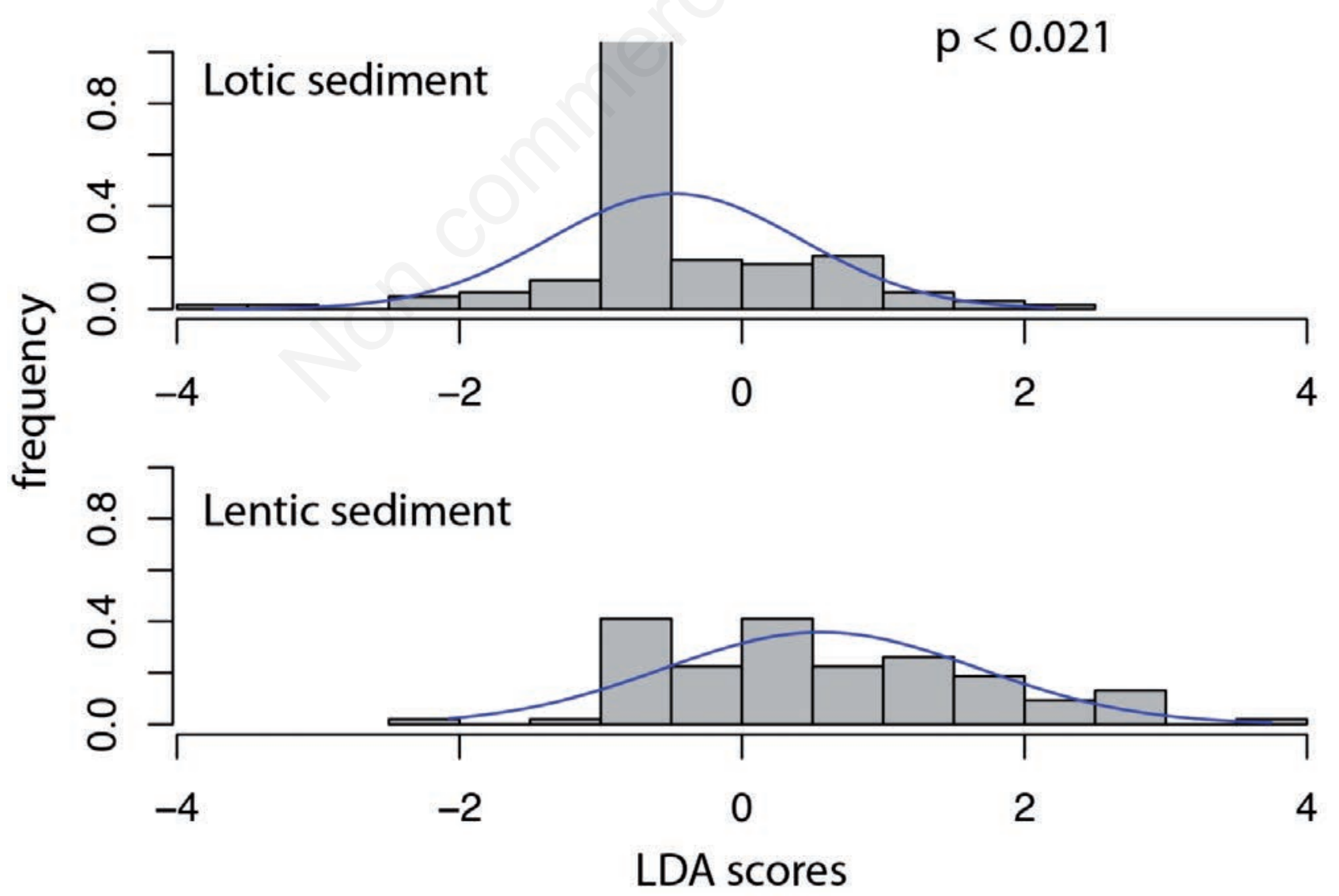

Fig. 4. Distribution of discriminant (LDA) scores in lentic and lotic status of sediment layers. 
al., 2010a, 2010b, 2010c). Remains of A. harpae, E. lamellatus, Disparalona rostrata (Koch, 1841), Pleuroxus trigonellus (O. F. Müller, 1785), and Sida crystallina (O. F. Müller, 1776) indicate presence of macrophytes in the oxbow (Gulyás and Forró, 1992; Korhola and Rautio, 2001; Korponai et al., 2010a). Large floods occurred mainly in spring and autumn, while lower water levels in summer promoted the development of the macrophyte belt in Marótzugi-Holt-Tisza. As a consequence, remains of phytophyllous cladocerans were found also in the lotic layers of the core (Figs. 2 and 3). Cl-1 zone covers the timespan 1876-1950, that can be described as the period of regulation works at River Tisza, when subsequent large floods inundated its floodplains covered them with thick sediment layers. During floods thick suspended solids layers buried all habitats that prevented recovery of cladoceran community from egg banks (Vaničková et al., 2011), but resting eggs could been washed in with floods from other habitats allowing development of new populations after floods (Havel et al., 2000). The low number of remains in this core section therefore can be explained by the slow recovery of the cladoceran community from sediment egg banks.

In Cl-2 and Cl-3 zones (between 1950-1970) the co-occurrence of a high proportion of Bosmina longirostris and of phytophyllous cladoceran species indicates the development of a macrophyte bed with large open water patches due to a lentic water regime (Galbarczyk-Gąsiorowska et al., 2009). In Cl-4 zone, the absolute dominance of B. longirostris since 1970 is related to strong human impacts. In fact, small bodied cladocerans as B. longirostris typically dominate in eutrophic waters with high fish abundance (Jeppesen et al., 2011; Goslar et al.,1999; Galbarczyk-Gąsiorowska et al., 2009). The high proportion of B. longirostris in Marótzugi-Holt-Tisza can be related to a fish effect, since this oxbow has been utilized as a fish pond since 1961.

The majority of species composing the cladoceran assemblages found in the sediment studied were common throughout the whole core. We did not find remarkable differences in species compositions of lotic and lentic communities, but densities were higher during lentic conditions. Three-fold more remains were found in lentic layers than in lotic ones. Remains of mud dwellers, i.e., Iliocryptus sp. and Monospilus dispar, were found exclusively in lotic sediment layers. These species prefer sandy or muddy surfaces, which establish after floods (Sebestyén, 1965, 1970, Frey, 1986, 1988, Kattel et al., 2007). Species which were found in lentic layers of Marótzugi-Holt-Tisza (A. rustica, A. excisa, C. piger, $K$. latissima and Simocephalus sp.) were recorded from shallow lakes and ponds in Hungary in macrophytes belts (Korponai et al., 2010a). Galbarczyk-Gąsiorowska et al. (2009) found that remains of A. excisa, and K. latissima were associated with macrophyte occurrence in a lakebog transition zone in Stare Biele mire.

Although a large number of common species were found both in lotic and lentic layers, LDA analysis confirmed separation of the two stages (Fig. 4). For testing how cladocerans can indicate lotic/lentic states, we redefined lotic and lentic attributes of sediment layers by LDA scores. The two LDA-based regime were clearly different from each other, thus outlining that lotic and lentic water regimes can be distinguished based on their cladoceran communities . In order to understand how much LDAbased lotic-lentic categories correspond to proportion of fine sand, we compared how many layers changed their attributes. We found that $71 \%$ of sediment layers kept their original status, $14 \%$ changed their own character from lotic to lentic, while $15 \%$ of layers turned from lentic to lotic. This means that if we determine lotic or lentic conditions based only on subfossil Cladocera communities, our determination would be correct in $71 \%$ of cases.

\section{CONCLUSIONS}

Marótzugi-Holt-Tisza has gradually evolved from a lotic to a lentic (pond) system during the last $\sim 150$ years, and all the stages of this evolution were recorded in sediment studied. Marótzugi-Holt-Tisza was lotic until 1950 but has now become a lentic system. This transition was determined by the frequent floods of River Tisza and it was reflected by changes in the zooplankton community. Lotic systems showed lower zooplankton densities, but were typically characterized by mud dweller species, as Monospilus dispar and Iliocryptus sp. Bosmina longirostris can be regarded as indicator of human impact, since the studied oxbow has been intensively utilized as a fishpond for anglers.

This work showed that flood events can drive changes in cladoceran communities, and that subfossil Cladocera remains can be successfully used to track shifts from lotic to lentic water regimes in oxbow lakes.

\section{ACKNOWLEDGMENTS}

This study was financially supported by the Hungarian National Science Foundation, OTKA-T 049098 and the Hungarian National Research and Development Program BALÖKO 3B022/04, TÁMOP 4.2.2-08/1-2008-0020, TÁMOP 4.2.1/B-09/1/KONV-2010-0006.

\section{REFERENCES}

Babka B, Futó I, Szabó S, 2011. Clustering oxbow lakes in the Upper-Tisza Region on the basis of stable isotope measurements. J. Hydrol. 410:105-113. 
Botár I, Károlyi Zs, 1971. [The regulation of the Tisza. Part I. (1846-1879)].[Article in Hungarian]. Vizdok, Budapest.

Braun M, Papp I, Korponai J, Lukács V, Gyulai I, Forró L, Hubay K, Szalóki I, 2010. [Traces of water level changes in the sediment of Marótzug Oxbow Lake].[Article in Hungarian with English abstract]. Hidrol. Közl. 90:20-22.

Braun M, Tóth A, Alapi K, Dévai G, Lakatos G, Posta J, Szalóki I, 2000. Environmental history of oxbow ponds: a sediment geochemical study of Marót-zugi-Holt-Tisza. Tiscia 5:133-138.

Csépes E, Bancsi I, Végvári P, Aranyné Rózsavári A, 2003. [Investigation of alluvion in the middle section of River Tisza (from Kiköre to Szolnok)].[Article in Hungarian]. Proc. $21^{\text {st }}$ Ann. Meet. Hungarian Hydrological Society 2-3:1-10.

Frey DG, 1950. The taxonomic and phylogenetic significance of the head pores of the Chydoridae (Cladocera). Int. Rev. Ges. Hydrobiol. 44:27-50.

Frey DG, 1962. Cladocera from the Eemian interglacial of Denmark. J. Paleontol. 36:1133-1154.

Frey DG, 1986. Cladocera analysis, p. 692-667. In: B.E. Berglund (ed.), Handbook of palaeooecology and palaeohydrology. J. Wiley \& Sons, Chichester.

Frey DG, 1988. Littoral and offshore communities of diatoms, cladocerans and dipterous larvae, and their interpretation in paleolimnology. J. Paleolimnol. 1:179-191.

Frey DG, 1991. First subfossil records of Daphnia headshields and shells (Anomopoda, Daphniidae) about 10000 years old from northernmost Greenland, plus Alona guttata (Chydoridae). J. Paleolimnol. 6:193-197.

Galbarczyk-Gąsiorowska L, Gąsiorowski M, Szeroczyńska K, 2009. Reconstruction of human influence during the last two centuries on two small oxbow lakes near Warsaw (Poland). Hydrobiologia 631:173-183.

Goslar T, Ralska-Jasiewiczowa M, van Geel Łącka B, Szeroczyńska K, Chróst L, Walnus A, 1999. Anthropogenic changes in the sediment composition of Lake Gościąż (central Poland), during the last 330 yrs. J. Paleolimnol. 22:171-185.

Goulden CE, Frey DG, 1963. The occurrence and significance of lateral head pores in the genus Bosmina (Cladocera). Int. Rev. Ges. Hydrobiol. 48:513-522.

Grimm EC, 1987. CONISS: A FORTRAN 77 program for stratigraphically constrained cluster analysis by the method of incremental sum of squares. Comput. Geosci. 13:13-35.

Gulyás P, Forró L, 1999. [A guide for the identification of Cladocera occurring in Hungary].[Book in Hungarian]. KGI, Budapest.

Gulyás P, Forró L, 1992. Composition and abundance of microcrustacean fauna in the Upper Reservoir (Hídvégi-tó) of the Kis-Balaton. Miscnea Zool. Hung. 7:39-51.

Havel JE, Eisenbacher EM, Black AA, 2000. Diversity of crustacean zooplankton in riparian wetlands: colonization and egg banks. Aquat Ecol. 34:63-76.

Heiri O, Lotter AF, Lemcke G, 2001. Loss on ignition as a method for estimating organic and carbonate content in sediments: reproducibility and comparability of results. J. Paleolimnol. 25:101-110.

Istvánovics V, Honti M, 2011. Phytoplankton growth in three rivers: The role of meroplankton and the benthic retention hypothesis. Limnol. Oceanogr. 56:1439-1452.
Jeppesen E, Nõges P, Davidson TA, Haberman J, Nõges T, Blank K, Lauridsen TL, Søndergaard M, Sayer C, Laugaste R, Johansson LS, Bjerring R, Amsinck SL, 2011. Zooplankton as indicators in lakes: a scientific-based plea for including zooplankton in the ecological quality assessment of lakes according to the European Water Framework Directive (WFD). Hydrobiologia 676:279-297.

Juggins S, 2009. rioja: Analysis of Quaternary Science Data, R package ver. 0.5-6. Available from: http://cran.r-project.org/ package $=$ rioja.

Kattel GR, Battarbee RW, Mackay A, Birks HJB, 2007. Are cladoceran fossils in lake sediment samples a biased reflection of the communities from which they are derived? J.Paleolimnol. 38:157-181.

Kiss T, Fejes A, 2000. Flood caused sedimentation on the foreshore of the River Tisza. Acta Geograph. 37:51-55.

Knowlton ME, Jones JR, 1997. Trophic structure of Misouri River floodplain lakes in relation to basin type and connectivity. Wetlands 17:468-475.

Korhola A, Rautio M, 2001. 2. Cladocera and other Branchiopod crustaceans, p. 1-38. In: J.P. Smol, H.J.B. Birks and W. M. Last (eds.), Tracking environmental change using lake sediments, vol. 4. Zoological Indicators. Kluwer Academic Publishers, Dordrecht.

Korponai J, Braun M, Buczkó K, Gyulai I, Forró L, Nédli J, Papp I, 2010a. Transition from shallow lake to a wetland: a multi-proxy case study in Zalavári Pond, Lake Balaton, Hungary. Hydrobiologia 641:225-244.

Korponai J, Braun M, Gyulai I, Forró L, Nédli J, Papp I, 2010 b. [Are the Cladocera remains in sediment suitable for reconstruction of diversity of cladoceran community of lakes?]. [Article in Hungarian with English abstract]. Hidrol. Közl. 90:66-68.

Korponai J, Braun M, Gyulai I, Forró L, Nédli J, Papp I, 2010c. [Paleolimnological reconstruction of naturally cut-off oxbow by geochemical and Cladocera remains proxies].[Article in Hungarian with English abstract]. Hidrol. Közl. 90:68-70.

Korponai J, K. Varga KA, Lengré T, Papp I, Tóth A, Braun M, 2011. Paleolimnological reconstruction of the trophic state in Lake Balaton (Hungary) using Cladocera remains. Hydrobiologia 676:237-248.

Lászlóffy W, 1982. [The River Tisza].[Book in Hungarian]. Akadémiai Kiadó, Budapest: 610 pp.

Luoto TP, Nevalainen L, Kultti S, Sarmaja-Korjonen K, 2011: An evaluation of the influence of water depth and river inflow on quantitative Cladocera-based temperature and lake level inferences in a shallow boreal lake. Hydrobiologia 676:143-154.

Müller Z, Dévai Gy, Miskolczi M, Kiss B, Tóth A, Nagy S, Grigorszky I, Jakab T, 2000. [Study on dragonflies as indicators of biotope heterogeneity in the active floodplain of River Tisza between Tiszabercel and Gávavencsellő].[Article in Hungarian with English abstract]. Hidrol. Közl. 56:373-376.

Nyárádi L, 1900. [Water regulation and floodprotection, p. 278294]. In: S. Borovszky and J. Sziklay (eds.), [Counties and cities of Hungarian Kingdom].[Book in Hungarian]. Budapest.

Oksanen J, Blanchet GJ, Friendly M, Kindt R, Legendre P, McGlinn D, Minchin PR, O’Hara PB, Simpson GL, Solymos 
P, Stevens MHH, Szoecs E, Wagner H, 2016. vegan: Community Ecology Package. R package version 2.4-1. Available from: https://CRAN.R-project.org/package=vegan.

Pálfai I, 2001. [Oxbow-lakes in Hungary].[in Hungarian with English abstract]. Ministry for Transport and Water Management: Budapest, Budapest.

Pujin V, Ratajac R, 1988. Structure and dynamics of zooplanktonin the dead Theiss. Tiscia 23:51-59.

Pujin V, Ratajac R, Djukić N, 1986. [Ein Beitrag zur limnologischen Untersuchungen der Carska bara].[Article in German]. Tiscia 21:69-80.

R Development Core Team, 2010. R: A Language and Environment for Statistical Computing. R Foundation for Statistical Computing, Vienna, Austria. Available from: http://www.Rproject.org

Ratajac R, 1989. The composition and the dynamics in population of the dominant Crustacea species in Mrtva Tisza. Tiscia 24:49-57.

Ratajac R, 1992. The structure and dynamics of Cladocera in the Yugoslavian section of the River Tisza. Tiscia 26:59-61.

Schweitzer F, Nagy I, Alfoldi L, 2002. [Relationship between the formation of point bars and natural levees and flood bed sedimentation along the middle stretches of Tisza River].[Article in Hungarian]. Föld. Ért. 51:257-278.

Sebestyén O, 1965. [Cladocera studies in Lake Balaton III. Preliminary studies for lake history investigations].[Article in Hungarian with English abstract]. Annal. Biol. Tihany 36:229-256.

Sebestyén O, 1969. [Cladocera studies in Lake Balaton IV. Quaternary remains in the sediment of Lake Balaton I].[Article in Hungarian with English abstract]. Annal. Biol. Tihany. 36:229-256.

Sebestyén O, 1970. [Cladocera studies in Lake Balaton IV. Quaternary remains in the sediment of Lake Balaton II].[Article in Hungarian with English abstract]. Annal. Biol. Tihany. 37:247-279.).

Sebestyén O, 1971. [Cladocera studies in Lake Balaton IV. Quaternary remains in the sediment of Lake Balaton III].[Article in Hungarian with English abstract]. Annal. Biol. Tihany. 38:227-268.

Szeroczyńska K, Sarmaja-Korjonen K, 2007. Atlas of subfossil Cladocera from central and northern Europe. Friends of the Lower Vistula Society, Świecie, Poland.

Vadadi-Fülöp Cs, 2009. Zooplankton (Cladocera, Copepoda) dynamics in the River Danube upstream and downstream of Budapest, Hungary. Opusc. Zool. Budapest 40:87-98.

Vadadi-Fülöp Cs, Mészáros G, Jablonszky Gy, Hufnagel L, 2008. The zooplankton of the Ráckeve-Soroksár Danube: spatio-temporal changes and similarity patterns. Appl. Ecol Env. Res. 6:121-148.

Vallentyne JR, 1955. Sedimentary chlorophyll determination as a palaeobotanical method. Can. J. Bot. 33:304-313.

Vaníčková I, Seda J, Petrusek A, 2010. The stabilizing effect of resting egg banks of the Daphnia longispina species complex for longitudinal taxon heterogeneity in long and narrow reservoirs. Hydrobiologia 643:85-95.

Whiteside MC, Williams JB, White CP, 1978. Seasonal abundance and pattern of Chydorid, Cladocera in mud and vegetative habitats. Ecology 59:1177-1188.

Wolfe BB, Hall RI, Last WM, Edwards TWD, English MC, Karst-Riddoch TL, Paterson A, Palmini R, 2006. Reconstruction of multi-century flood histories from oxbow lake sediments, Peace-Athabasca Delta, Canada. Hydrol. Process. 20:4131-4153.

Zsuga K, 1981. Benthic Entomostraca fauna of the Tisza and its tributaries. Tiscia 16:183-190.

Zsuga K, 1998. Spatial heterogeneity and mosaic-like structure of zooplankton in Kisköre Reservoir. Int. Rev. Hydrobiol. 83:199-202.

Zsuga K, 1999. Zooplankton investigations in the Upper Tisa Region. Tiscia Monogr. Ser. 4:393-399.

Zsuga K, Tóth A, Pekli J, Udvari Zs, 2004. [The changes in the zoopklankton of the watershed of the River Tisza from 1950s to the present].[Article in Hungarian with English abstract]. Hidrol. Közl. 84:175-178. 